\title{
DO VAZIO AO ESPAÇO PÚBLICO: REQUALIFICANDO PAISAGENS, REESTRUTURANDO TERRITÓRIOS
}

FROM THE VOID TO PUBLIC SPACE: REQUALIFYING LANDSCAPES, REORGANIZING TERRITORIES

\author{
Eugenio Fernandes Queiroga \\ Doutor em Arquitetura e Urbanismo e professor doutor pela FAUUSP, professor titular da FAU-PUC- \\ Campinas e pesquisador do $\mathrm{CNPq}$ \\ e-mail: queiroga@usp.br
}

\section{RESUMO}

O processo de urbanização brasileiro inclui, agora, a formação de novas metrópoles, não apenas nucleadas por capitais de estados. A região metropolitana de Campinas é a mais importante dessas novas realidades urbanas. Os seus antigos leitos ferroviários apresentam alta ociosidade, podendo se prestar para novos usos que, de maneira sistêmica, propiciem a requalificação da paisagem e contribuam para uma reestruturação do território metropolitano, favorecendo seus cidadãos. Mais que apresentar uma diretriz propositiva, este artigo enfatiza a importância das potencialidades da paisagem como elemento a ser considerado no planejamento territorial.

Palavras-chave: Região metropolitana, antigos leitos ferroviários, vazios, sistemas, transportes, parques lineares, espaço público, paisagem, território.

\begin{abstract}
Nowadays the brazilian urbanization process includes the formation of news metropolis, not only from capitals of members-states. The Campinas metropolitan region is the most important of the new urban reality. Its old railways are few used and it can receive new uses that, by a systemic way, would provide the qualification of landscape, contributing to restructure the metropolitan territory in favor of its citizens. More than proposing guidelines, this article emphasizes the importance of the landscape potentialities as an element to be considered in territorial planning.
\end{abstract}

Key words: Metropolitan region, old railways, voids, systems, transports, linear parks, public space, landscape, territory.

\section{INTRODUÇÃO}

As regiões metropolitanas, de fato ou de direito, constituem-se em número cada vez maior no país. Particularmente nos regiões Sul e Sudeste do Brasil, elas já não se dão apenas em torno das capitais, mas se estruturam pelo litoral e interior de diversos estados. Compreendê-las é esforço necessário e atual, são pólos dinâmicos da economia, lugares tensionados por interesses de diferentes escalas, em que questões socioambientais demandam uma gestão específica. Não basta traçar analogias com as primeiras metrópoles institucionalizadas no país nos anos 70, é necessário ter-se em conta o período atual, de reestruturação produtiva, da formação do que Milton Santos 
(1994) denominou de "meio técnico-científico-informacional", mas também de "período popular da história" (SANTOS, 2000). São nesses novos ambientes, densamente e cientificamente tecnicizados, que operam os interesses das grandes corporações e sobrevivem, em número cada vez maior e de maneira bastante criativa, parte expressiva dos pobres da nação.

Apresentam-se, aqui, algumas notas sobre o território da região metropolitana de Campinas, certamente a mais importante metrópole brasileira não-constituída a partir de uma capital estadual ou federal - a metrópole campineira, com 1,4\% da população brasileira, apresenta 4,2\% do PIB do país (EMPLASA, 2005). Sua paisagem é altamente reveladora de novos processos de urbanização que vêm se apresentando nas médias e grandes cidades brasileiras, próprias da reestruturação produtiva global que presenciamos desde as crises do petróleo dos anos 70.

Mas a paisagem, como acumulação desigual dos tempos (SANTOS, 1988), mesmo de nossas mais novas metrópoles, não é apenas fruto dos novos elementos da configuração territorial. Velhas estruturas, por vezes obsoletas, ainda marcam os novos processos espaciais. É o caso, para a metrópole campineira e muitas outras, dos antigos leitos ferroviários. Alguns já extintos, outros servindo apenas para cargas, muitos trilhos e poucos trens. Os antigos leitos férreos se constituem em barreiras aos tecidos urbanos, e, empobrecidos em utilização, provocam, por vezes, extensos vazios.

Do vazio ao espaço público, da requalificação da paisagem à reestruturação do território, são passos ambiciosos que não se podem dar individualmente, nem por imposição técnica nem política. Pretende-se, neste artigo, contribuir para a reflexão sobre a questão, sem receio de, para tanto, apresentar, inclusive, uma diretriz propositiva para o caso das antigas ferrovias da região metropolitana de Campinas. Salienta-se tratar-se de uma "proposta-pretexto" para afirmar a pertinência de estudos dialéticos e sistêmicos sobre a paisagem e o território, para reiterar a importância da paisagem como elemento a ser considerado no âmbito do planejamento territorial, dos espaços para a esfera de vida pública, se é que desejamos contribuir para a cidadania na metrópole contemporânea.

\section{NOTAS SOBRE O TERRITÓRIO DA REGIÃO METROPOLITANA DE CAMPINAS}

A região metropolitana de Campinas constituiu-se oficialmente em 2000. Situada a cerca de $100 \mathrm{~km}$ de São Paulo, no sentido norte-noroeste, apresenta área de 3.673 km² (1,5\% da área do estado de São Paulo) e, já naquela data, possuía população de mais de 2,3 milhões de habitantes (6,3\% do estado, segundo a Emplasa, 2005). A região é composta por 19 municípios: Americana, Artur Nogueira, Campinas, Cosmópolis, Engenheiro Coelho, Holambra, Indaiatuba, Itatiba, Jaguariúna, Monte Mor, Nova Odessa, Paulínia, Pedreira, Santa Bárbara d'Oeste, Santo Antonio da Posse, Sumaré, Valinhos e Vinhedo. Alguns não chegam a 20 mil habitantes, como Engenheiro Coelho, Holambra e Santo Antonio da Posse; outros possuem por volta 
de 200 mil residentes, como Americana, Hortolândia, Santa Bárbara d'Oeste e Sumaré; já Campinas ultrapassou um milhão de habitantes em 2004 (IBGE, 2005).
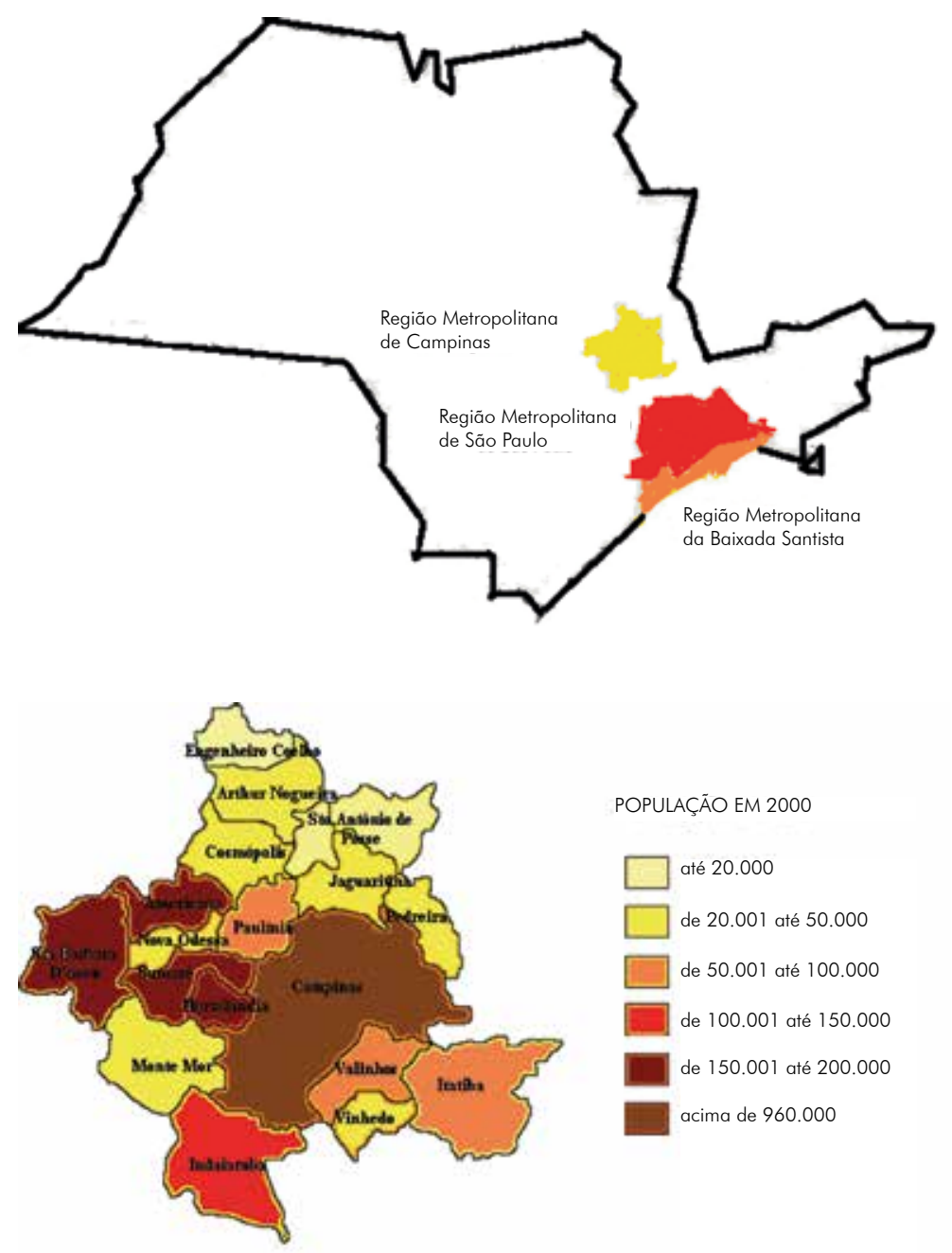

POPULAÇÃO EM 2000

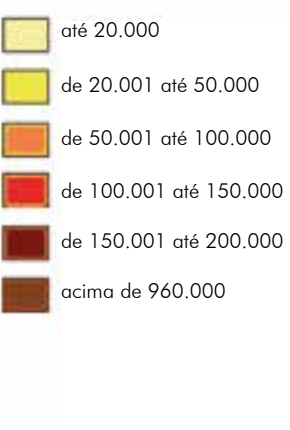

Figura 1: As regiões metropolitanas do estado de São Paulo Desenho: Queiroga, 2005; base: Emplasa, 2005
Figura 2: Os municípios da região metropolitana de Campinas - População Desenho: Queiroga, 2005; base: Emplasa, 2005 Fonte: IBGE, 2005

Apresenta dois claros compartimentos geomorfológicos; o primeiro, grosso modo, a leste do ribeirão Anhumas, constituído de relevo mais movimentado, morros e morrotes das bordas mais a oeste do escudo cristalino, formador da serra da Mantiqueira; o segundo, configurado por colinas amplas e médias a partir do derramamento basáltico no início da denominada Depressão Periférica do estado de São Paulo, formando expressivas manchas de latossolo vermelho e roxo bastante férteis, notadamente na porção norte-noroeste da região. Sob o ponto de vista hidrográfico, a metrópole campineira participa de três bacias de afluentes da margem direita do rio Tietê, de sul a norte: os rios Jundiaí, Capivari e Piracicaba. Da cobertura vegetal original restam apenas pequenos fragmentos isolados da floresta atlântica do planalto (mata semidecídua) e, em solos mais pobres, a sudoeste, manchas de cerrado pouco expressivas.

A região se desenvolveu a partir da expansão cafeeira do século 19, quando nela se implantou uma complexa rede ferroviária. Isso permitiu a Campinas tornar-se a mais 
importante cidade do interior paulista, centro de comércio e serviços especializados de uma vasta região atingindo, inclusive, alguns municípios do estado de Minas Gerais, situação que perdura até o presente.

Com a crise de 1929, diversifica-se sua economia. Nos transportes, iá nos anos 30, implanta-se o Aeroporto de Viracopos, nos anos 40 constrói-se a rodovia Anhangüera, seguindo de São Paulo rumo ao Triângulo Mineiro e estado de Goiás. A partir dos anos 50, no governo Juscelino Kubitscheck, instalam-se, na região, importantes indústrias multinacionais, ligadas ao setor automobilístico e químico, notadamente em Campinas e Paulínia, na época, distrito de Campinas. Nos anos 60 funda-se a segunda universidade estadual paulista, a Unicamp, segunda universidade sediada em Campinas, que já possuía uma Pontifícia Universidade Católica (PUC-Campinas).

A partir da crise do petróleo, inicia-se uma reestruturação produtiva em escala global. Na década de 1970, novas instalações industriais se implantam fora da Grande São Paulo, em um raio de cerca de $150 \mathrm{~km}$. Inicia-se um processo de dispersão "seletivamente concentrada" da indústria paulista, resultando no estabelecimento de uma "macrometrópole" (SOUZA,1978), onde o entorno começa a crescer mais que a metrópole paulistana. Campinas e municípios vizinhos vão receber importantes plantas industriais, inclusive a maior refinaria do país. Campinas, diante da instalação de diversos centros de pesquisa de relevância continental - $\mathrm{CPqD}$, telecomunicações, Laboratório Nacional de Luz Sincroton, nanotecnologia, Centro Tecnológico de Informática, atual CenPRA, Instituto Tecnológico de Alimentos, duas unidades da Embrapa, somados ao Instituto Agronômico de Campinas (criado, ainda, no tempo do Império) e às suas principais universidades, vai se constituir em um dos mais importantes centros universitários e de pesquisa nacional. Atualmente, a região metropolitana de Campinas é o principal pólo brasileiro nos setores industriais de telecomunicações e informática apresentando, além disso, um parque industrial bastante diversificado, do setor alimentício ao automobilístico, passando por papel e celulose, produtos químicos e farmacêuticos, entre outros.

No território metropolitano campineiro estrutura-se uma impressionante rede de autoestradas (rodovias Anhangüera, dos Bandeirantes, Santos Dumont, D. Pedro I, Adhemar de Barros, Milton Tavares de Souza e Magalhães Teixeira, entre as mais importantes). Instala-se, na virada para o século 21, uma crescente rede de fibraótica, servindo-se, em boa medida, das auto-estradas, ampliando as vantagens regionais, sobretudo para o capital corporativo que conta, também, com constantes melhorias no Aeroporto de Viracopos, já o mais importante em valor de cargas transportadas do país.

A complexidade econômica de regiões como as de Campinas, São José dos Campos, Baixada Santista, Sorocaba, Ribeirão Preto e mesmo de São Carlos-Araraquara, Bauru e São José do Rio Preto, permite-nos avançar para além das noções de macrometrópole ou de "complexo metropolitano expandido" (EMPLASA, 2005). Não se trata mais de mera expansão de atividades antes concentradas na metrópole paulistana, mas sim de um território mais complexo, de intensas relações econômicas e culturais, indo mesmo além dos limites paulistas, envolvendo o vale do Paraíba e a metrópole carioca, ampliando-se rapidamente, incluindo cidades mineiras. Trata-se da mais significativa 
parcela do meio técnico-científico-informacional brasileiro. Estamos diante de uma nova entidade urbana: a "Megalópole do Sudeste Brasileiro" (QUEIROGA, 2001).

A paisagem e o território da região metropolitana de Campinas não se constitui apenas em uma história de desenvolvimento econômico. Trata-se de um processo dialético no qual a concentração de riquezas atrai e deixa à margem expressivo contingente migratório, em um primeiro momento, e hoje, com a menor necessidade de mão-de-obra pouco qualificada, impõe o desemprego a parcelas crescentes da população já residente na metrópole. O território e a paisagem revelam e reforçam processos de segregação socioespacial crescentes, o urbano se fragmenta ainda mais em territórios precariamente urbanizados e outros luxuosamente urbanizados, o medo da violência gera ainda mais muros e seguranças, mais se amplia o crime organizado. Campinas é detentora de índices de criminalidade, "dignos" das maiores metrópoles brasileiras. Se, em Indaiatuba, por exemplo, há o maior número de campos de pólos privados do país, em Hortolândia o número de domicílios com ligação à rede de esgotos é inferior a 5\% do total. Se Vinhedo apresenta, em apenas um loteamento fechado, área superior à maior parte da cidade tradicional, em Pedreira a maioria dos trabalhadores (65\%) ganha até, no máximo, três salários mínimos (IBGE, 2005).

\section{A DECADENTE PAISAGEM FERROVIÁRIA DA METRÓPOLE CAMPINEIRA}

A implantação de extensa malha férrea no estado de São Paulo, impulsionada, sobretudo, pela economia cafeeira entre as três últimas décadas do século 19 e as três primeiras do século 20, propiciou não apenas o aparecimento de inúmeras cidades, mas o estabelecimento de uma rede urbana em muito estruturada pela rede ferroviária. De tal sorte que o território paulista se organizou fortemente, ao menos até os anos 70 do século passado, em regiões relacionadas às antigas companhias férreas.

Campinas se constituiu, graças ao café, em um dos mais importantes nós ferroviários já no último quartel do século 19. Nenhuma outra cidade interiorana era sede de duas das mais ricas estradas de ferro (Companhia Paulista de Estradas de Ferro, 1872, e a Companhia Mogiana de Estradas de Ferro, 1875). Saindo de Campinas, rumo a sudeste, os trilhos da Paulista faziam, em Jundiaí ( $\mathrm{km} \mathrm{0),} \mathrm{conexão} \mathrm{com} \mathrm{a} \mathrm{mais} \mathrm{lucrativa}$ das estradas de ferro do país, a São Paulo Railway Company (posteriormente Estrada de Ferro Santos-Jundiaí). Para norte, a Cia. Paulista ia até Colômbia (km 507), na divisa com Minas Gerais, às margens do rio Grande, passando, entre outras, por Americana, Rio Claro, São Carlos, Araraquara, Jaboticabal, Bebedouro e Barretos; para oeste, atingia a fronteira com Mato Grosso, em Panorama, às margens do rio Paraná, passando, entre outras, por Jaú, Bauru, Marília e Adamantina (km 516). A Cia. Mogiana, conhecida como a "ferrovia dos ramais", saindo de Campinas (km 0), coletava o café das importantes regiões de Mogi Mirim e Ribeirão Preto, atingido até Araguari (Km 724), antes passando por Uberaba e Uberlândia (MG), e, também em Minas Gerais, chegava até Passos (km 429) e Poços de Caldas (km 201), todas em Minas Gerais; em 
São Paulo, entre outras, os trilhos da Mogiana serviam em Mogi Mirim e Guaçu, São José do Rio Pardo, Ribeirão Preto e Franca. Por Campinas trafegavam também os trens da Estrada de Ferro Sorocabana, constituindo importante quebra do monopólio dos ingleses na descida até o porto de Santos, passando por Mairinque, Sorocaba e São Paulo, entre outras. Com menor expressão, havia os trens da Companhia Funilense de estradas de ferro, que iam até o bairro do Funil, atual município metropolitano de Cosmópolis, e os do Ramal Ferroviário de Campinas, que chegavam até as fazendas de café dos distritos de Souzas e Joaquim Egídio.

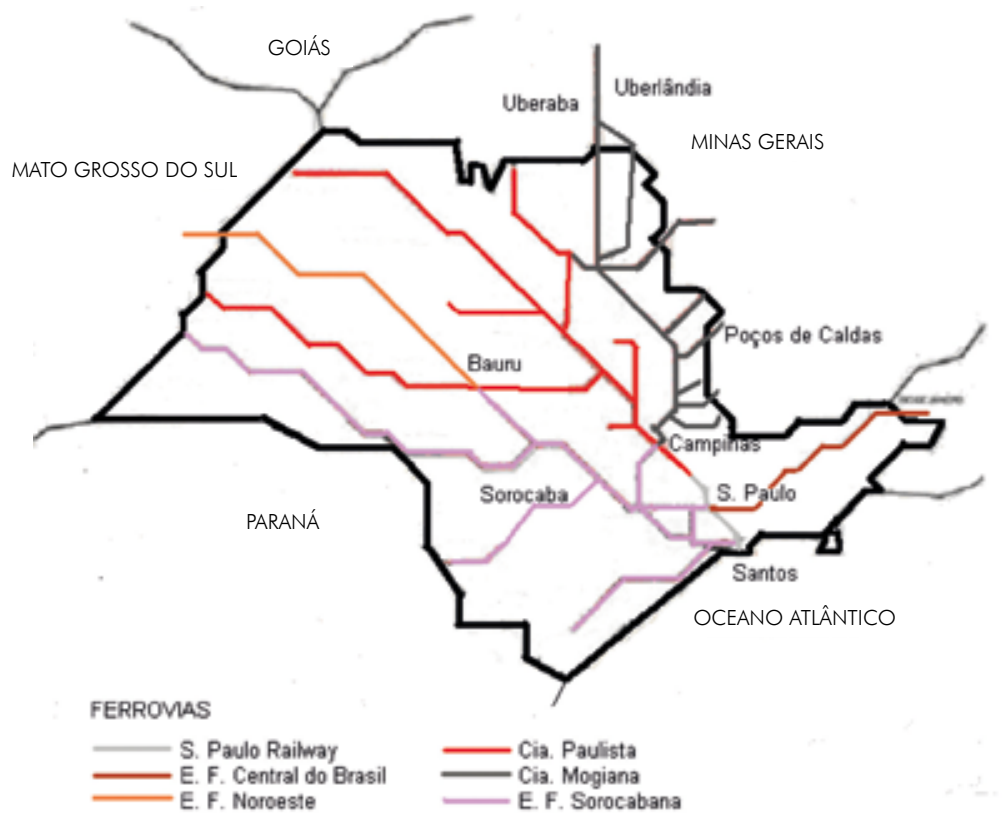

Figura 3: Principais ferrovias no estado de São Paulo na década de 1950 Desenho: Queiroga, 2005; base: Bitencourt, 2004

Pelos trilhos campineiros circulavam, além do café, seus barões e pessoas de todas as classes sociais, as mercadorias do estrangeiro, as informações nacionais e estrangeiras, a cultura metropolitana da época. A modernidade européia já não era privilégio apenas dos nobres instalados na capital do império brasileiro. A riqueza do café e a malha ferroviária campineira propiciavam à cidade tornar-se grande centro comercial e de serviços para extensos territórios interioranos. Não fossem os surtos de febre amarela do final século 19, e a passagem para o regime republicano, a rivalidade, na época, entre Campinas e a capital do estado, poderia ter tido outros desdobramentos.

A partir da crise de 1929, o declínio da cultura cafeeira implica em prenúncio da decadência do transporte ferroviário paulista. A queda do café, em volume e valor, transportado pela ferrovia, logo significou menor margem de lucro das empresas ferroviárias paulistas. Parte dos recursos outrora investidos na cultura cafeeira e no setor ferroviário foi transferida para outras culturas e atividades urbanas, notadamente fabris, a partir das políticas de industrialização promovidas por Getúlio Vargas e por Juscelino Kubitscheck. Tal industrialização se fez de maneira concentrada em algumas cidades, principalmente em São Paulo e alguns municípios vizinhos, mas também Campinas, 
Sorocaba, Jundiaí, São José dos Campos, Taubaté e Ribeirão Preto, para citar apenas os principais municípios. Paulatinamente, essa mudança de endereço das atividades econômicas e de seus respectivos mercados foram propiciando inversões crescentes de capitais privados nos novos setores mais lucrativos, a ponto de a malha férrea ter sido estatizada entre os anos 50 e 60. Evidentemente, não se tratava de uma estratégia do Estado, para melhor controlar esse decadente, porém ainda importante meio de transporte, mas sim o interesse dos capitais privados em livrarem-se desses ativos de baixa liquidez, exigindo inversões crescentes para se tornarem competitivos diante dos novos meios de transportes sobre pneus.

Ao longo da malha ferroviária de Campinas e sua região imediata, a paisagem foi se alterando. Inicialmente, a ferrovia gerava avanços econômicos, nas estações se fortaleciam as atividades centrais; nas imediações, armazéns de distribuição; a seguir, fábricas de gêneros alimentícios, têxteis, máquinas de beneficiamento do café, mais adiante cerâmicas e olarias, saindo da zona urbana, os campos cultivados, café para todo o lado, mas também cana-de-açúcar.

Culturas localizadas, como a uva em Vinhedo ou o figo em Valinhos, são sinais de imigrantes já proprietários de terras. Italianos, em maior número, vão adquirir sítios e fazendas, sobretudo em Valinhos e Vinhedo; suíços assentaram-se ao sul de Campinas e Indaiatuba; letos marcaram o território de Nova Odessa e a origem da cidade; norte-americanos, vindos dos derrotados estados sulistas, estabeleceram plantations de algodão e melancia em Santa Bárbara d'Oeste e Americana.

Os últimos a chegar foram os holandeses, mas já se estabeleceram de forma independente da lógica ferroviária. Marcaram de forma ainda mais característica a paisagem, com sua produção de flores, com sua organização cooperativa. Em 1991, Holambra, com seu pequeno aglomerado urbano e produtivo território agrícola, é um dos últimos municípios a criar-se na região.

Com o declínio da ferrovia, notadamente na segunda metade do século passado, as atividades econômicas a elas ligadas vão, em maior ou menor medida, entrar também em declínio. De áreas mais valorizadas passam a ser, por vezes, as mais desvalorizadas,
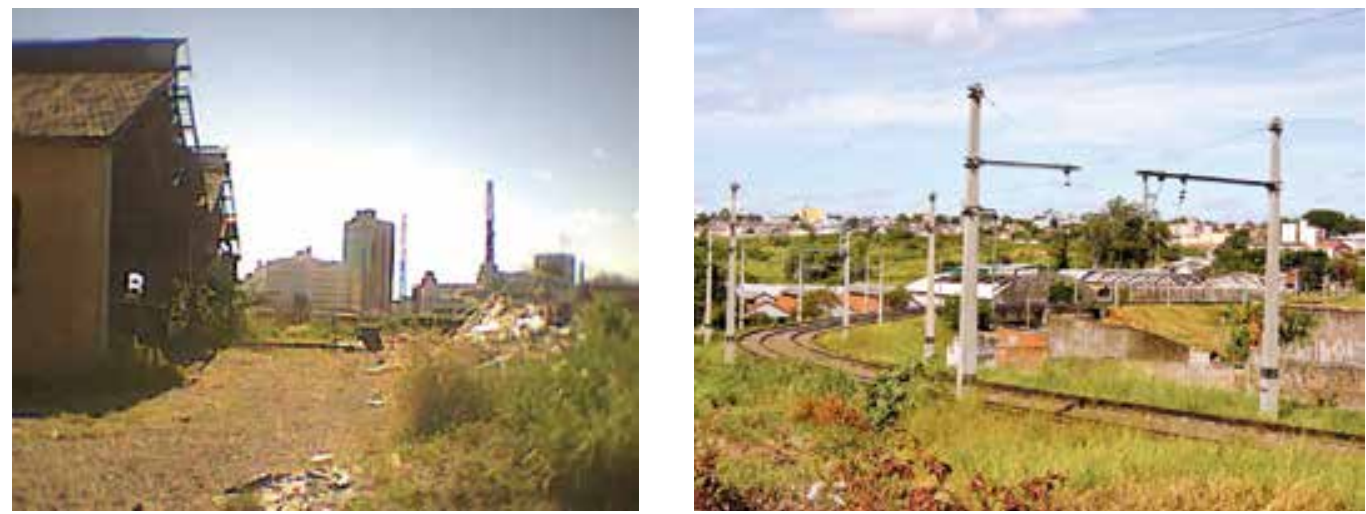

Figuras 4 e 5: Velhos galpões abandonados - novos vazios urbanos, bem próximos ao centro de Campinas, nos trilhos da Paulista

Foto: Bitencourt, 2004; Queiroga, 2004 
como as áreas na Estação de Campinas, da Cia. Paulista, outrora a mais importante da região, bem no centro da cidade, terminando o século 20 com imóveis abandonados, ruas inseguras, propícias à prostituição. Também as áreas industriais ferroviárias vão perder sua forte dinâmica, várias instalações são fechadas ou encontram-se subutilizadas. Algumas indústrias que permanecem em boa atividade, como a Rações Anhangüera, em Campinas, em nada se ocupam de sua imagem na paisagem, compondo, com as instalações campineiras, quase totalmente demolidas das falidas Indústrias Reunidas Matarazzo, um cenário desolador. Mas ninguém se abala com isso, as cidades, agora, viram-se de costas para os antigos leitos ferroviários. São poucas as ações de revitalização efetivadas até o presente em toda a metrópole de Campinas.

\section{RIOS, TRILHOS E PAISAGENS}

Diante da natureza do transporte ferroviário, buscam-se, nos traçados de suas estradas, evitar as declividades acentuadas. Na atual região metropolitana de Campinas, por razões técnicas e econômicas, as antigas estradas de ferro, em grande medida, localizam-se em paralelo a rios e ribeirões, optando por seguir uns ou outros em função da direção pretendida. Margeando seus vales, nas primeiras cotas seguras após as planícies de inundação (hoje, com a urbanização, nem sempre essas altimetrias são ainda tão seguras), realizando, assim, poucos aterros e obras de arte.

Os trilhos da Cia. Paulista acompanham o ribeirão Pinheiros entre Vinhedo e Valinhos; no entanto, em Campinas, diante da posição da área central da cidade, distante de curso d'água mais expressivo, optou-se por outra estratégia de traçado: sobre o espigão que divide as águas da bacia do rio Capivari e as do Piracicaba. Assim, de forma menos usual, está a Estação de Campinas, na cota mais alta em relação à área urbana do município no século 19, dominando a paisagem. Nos demais municípios da atual metrópole campineira, os trilhos da Paulista seguem paralelos a cursos d'água - Ribeirão Jacuba em Hortolândia e Sumaré, rio Quilombo em Nova Odessa e Americana.

A posição central e no espigão da Estação Campinas da Cia. Paulista obrigou a Mogiana e a Sorocabana a buscarem tal cota para realizar entroncamentos e baldeações de pessoas e mercadorias, ainda que a principal estação da Mogiana se instalasse um pouco mais distante, no bairro do Guanabara. Saindo de Campinas rumo ao sul, a Sorocabana segue, inicialmente, em cotas intermediárias, aproximando-se, depois, do rio Capivari e cruzando-o antes de chegar em Indaiatuba. Já a Mogiana segue rumo norte após a Estação Guanabara, primeiro em cotas intermediárias, paralelas ao córrego do Serafim, depois, já em menores altitudes, seu traçado é paralelo ao ribeirão Anhumas, cruzando o Atibaia e o Jaguari, já em Jaguariúna.

Para a Funilense, em Campinas, já no atual distrito de Barão Geraldo, a ferrovia se situava em paralelo ao ribeirão das Pedras até Paulínia, seguindo outros ribeirões até o antigo bairro do Funil (atual município de Cosmópolis). $\bigcirc$ Ramal Ferroviário de Campinas chegava ao distrito de Souzas, margeando o córrego dos Pires e, após cruzar 
o rio Atibaia, seguia para o distrito de Joaquim Egídio ao lado do ribeirão das Cabras, chegando até a fazenda de mesmo nome.

Já a moderna linha férrea, denominada "Corredor de Exportação", implantada entre os anos 80 e 90 pela extinta Fepasa, apresenta traçado mais retilíneo, com várias obras de arte e grandes taludes de corte e de aterro; mesmo assim, em Indaiatuba, a referida ferrovia se apresenta paralela ao rio Jundiaí, ainda que, é bem verdade, a uma distância bem maior do curso d'água que as ferrovias do século 19.

Em fim, tratam-se, em maior medida, de paisagens fluviais, vales, em geral, de pouca largura (raramente excedendo a um $\mathrm{km}$, freqüentemente não ultrapassando 300 metros) que receberão, em suas proximidades, os trilhos e seus trens. Em cada parada, um aglomerado urbano. Hoje, entre tais concentrações urbanas, pontuam-se, nos vales, algumas fábricas e olarias, quase sempre construções de décadas atrás; no mais, apresentam-se inúmeras várzeas com vegetação bastante alterada, restos de matas ciliares degradadas, vegetação palustre autóctone, gramíneas, alguma pastagem, pouco gado, pouco valor de mercado. Trata-se de áreas bastante ociosas no presente, verdadeiros vazios.

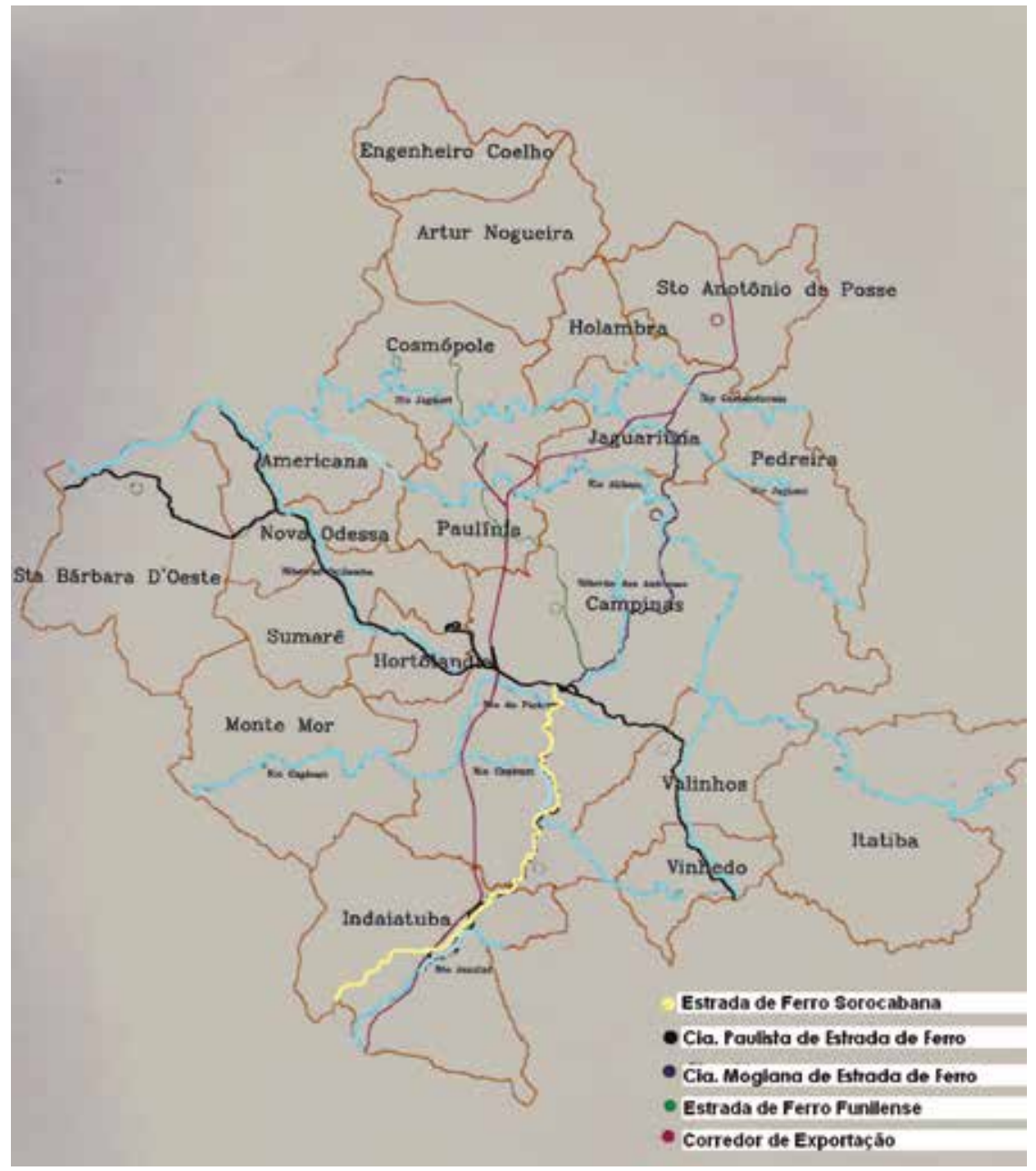

Figura 6: A região metropolitana de Campinas - Rios e ferrovias Desenho: Bitencourt, 2004; revisão:

Queiroga, 2005 


\section{AS FERROVIAS E SEU PAPEL ESTRUTURADOR DE TECIDOS URBANOS}

Se, no sentido longitudinal, as ferrovias são indutoras da urbanização, sua transposição sempre se constitui em obstáculo ao desenvolvimento pleno dos tecidos urbanos. Dessa forma, as ferrovias quase sempre se constituem em elementos importantes da estruturação urbana, caracterizando distintamente os lugares urbanos de um lado e do outro da linha, valorizando mais essa ou aquela porção do território e da paisagem urbana. Para a metrópole campineira caracterizada por um desmedido processo de expansão territorial fragmentada, a existência de vários leitos ferroviários vem, no presente, contribuir para tal situação na medida em que, como barreiras, estimulam a formação de vazios urbanos e do crescimento urbano fragmentado.

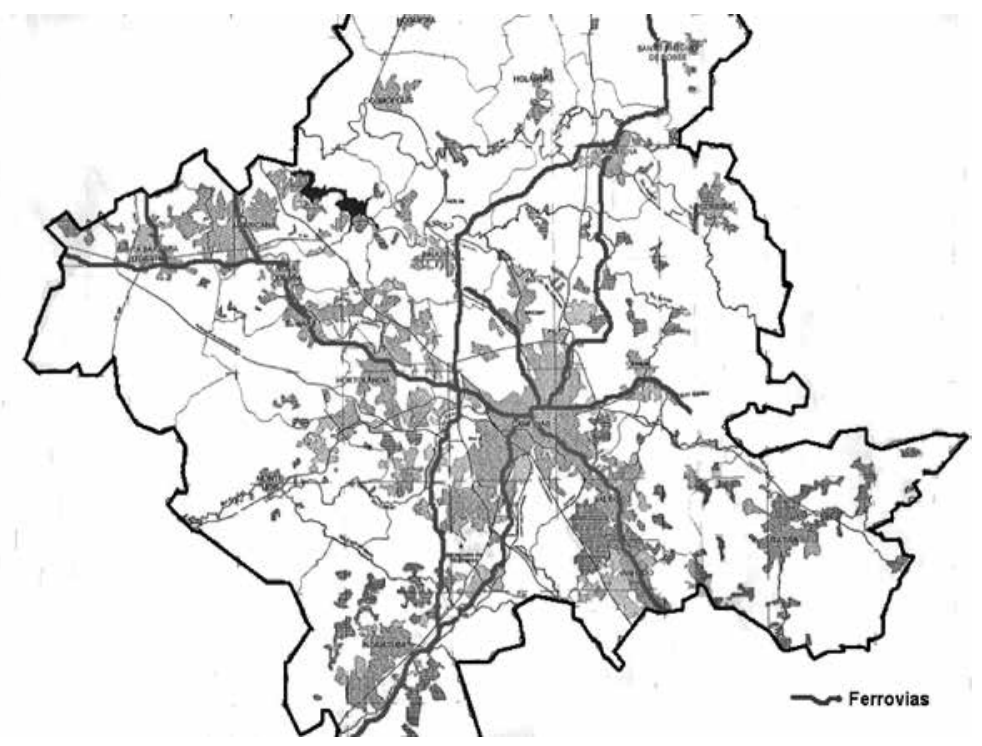

Figura 7: Região

metropolitana de Campinas - manchas de urbanização em 2000

Desenho: Queiroga, 2005; base: NESUR-UNICAMP; Embrapa

Na região metropolitana de Campinas, diante da freqüente situação de paralelismo, há pouco mencionada, entre os trilhos férreos e os cursos d'água, a maior parte das cidades apresenta, na linha férrea, o primeiro elemento de segregação socioespacial.

As cidades da metrópole campineira apresentam, em sua maioria, seus centros em cotas superiores às das antigas linhas férreas - exceção maior é Campinas, mas aí a ferrovia corre no divisor de águas, estando, portanto, ambos os lados da área mais antiga da cidade, abaixo da cota dos trilhos da Cia. Paulista. Nas cidades preexistentes à ferrovia, esta se localizou abaixo do antigo núcleo principal, evitando desapropriações em áreas urbanas mais consolidadas e de estrutura fundiária mais fragmentada, ocupando cotas mais baixas e desocupadas próximas aos cursos d'água, de menores custos iniciais. Esse foi o caso de Americana, Santa Bárbara d'Oeste, Indaiatuba, Valinhos, Vinhedo, Jaguariúna, Pedreira e Monte Mor. As cidades, ou aglomerados urbanos que surgiram a partir da ferrovia, também não se estabeleceram em cotas inferiores às da ferrovia, quando esta margeava um vale de rio, pois isso significaria riscos de enchentes desnecessários - casos de Hortolândia e Nova Odessa. 
Em inúmeras cidades da metrópole de Campinas a estação ferroviária principal de cada cidade instalou-se muito próxima da área central, vindo o centro a expandir-se em direção à estação. Além das razões funcionais para isso, é digno de nota como a questão simbólica do poder religioso constituía-se em critério de localização das referidas estações, de tal sorte, que, nessas cidades, era típico ter-se a lgreja Matriz e sua praça ligadas diretamente por uma rua até a praça da estação de trens da cidade - esse é o caso de Campinas, Americana, Nova Odessa, Valinhos e Vinhedo. Isso quando a ligação não era ainda maior, como no caso de Sumaré, onde se prolongou a praça da lgreja Matriz até a praça da Estação, criando-se um sistema de praças ainda mais integrado entre os dois importantes lugares de vida pública - igreja e estação. Assim organizavam-se, simultaneamente, os fluxos, a paisagem e as relações simbólicas dos principais lugares públicos das cidades.

Curioso observar como, nessas cidades metropolitanas, houve maior preocupação urbanística na relação entre os espaços da igreja e da estação ferroviária central do que,
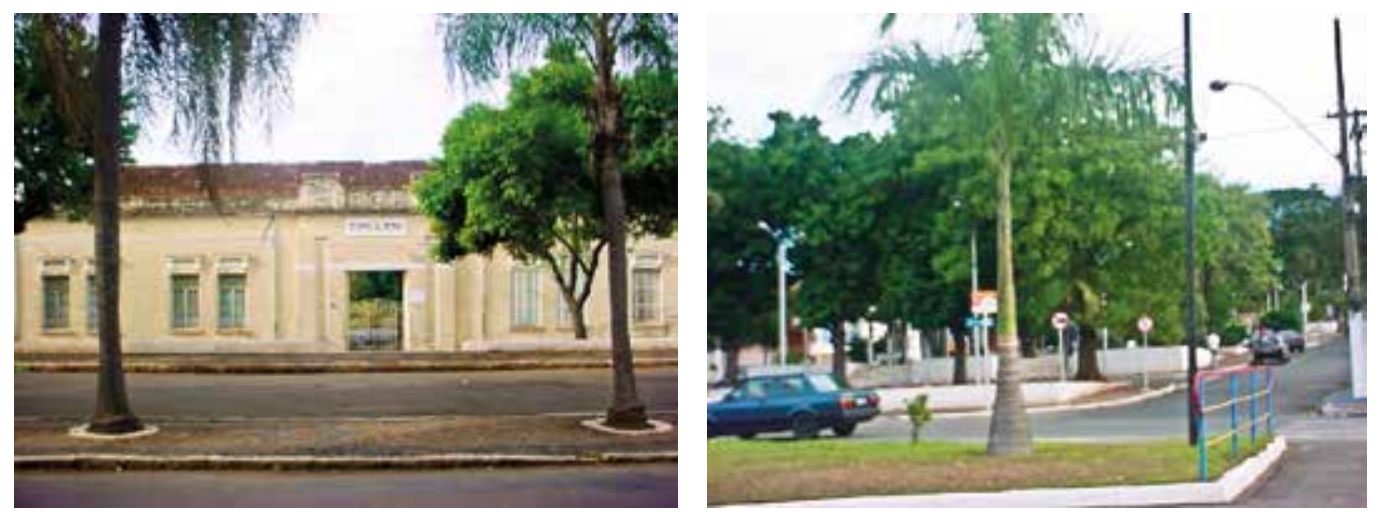

Figuras 8 e 9: Vistas parciais da Estação de Sumaré e da longa praça que articula a lgreja Matriz à estação Fotos: Queiroga, 2004
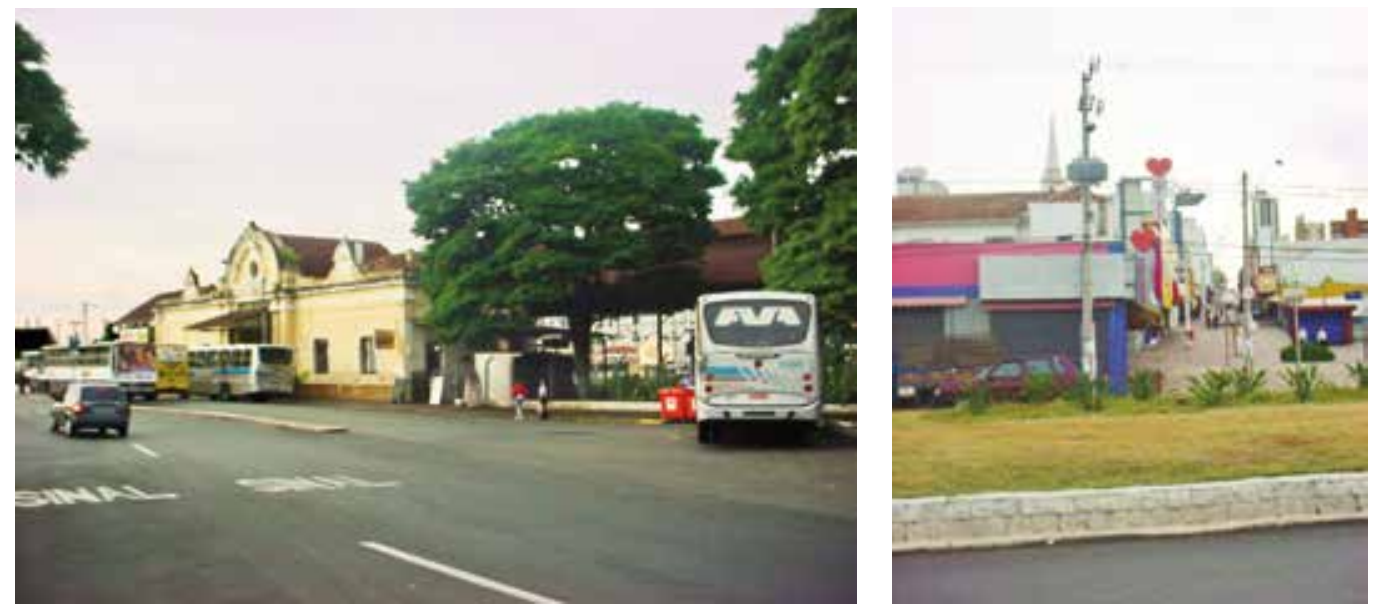

Figura 10: A Estação de Americana, seu largo hoje tomado por ônibus Foto: Queiroga, 2004

Figura 11: Rua de pedestres ligando a Estação Ferroviária de Americana à praça da lgreja Matriz Foto: Queiroga, 2004 
desde aquela época, qualquer outro conjunto de espaços da esfera de vida pública. Até os espaços do poder público não se situam de maneira tão estratégica no tecido urbano; pelo contrário, em muitos casos, tanto os edifícios da câmara municipal quanto da prefeitura acabam mudando de lugar, por discutíveis necessidades funcionais. Mesmo quando bem implantados, caso do Palácio dos Jequitibás, em Campinas, já estarão mais isolados quanto aos demais espaços públicos mais relevantes de suas respectivas cidades. Os espaços públicos mais importantes continuam no centro, a despeito de todo o processo de "urbanização difusa" (PORTAS, 1993) contemporâneo, tão característico da metrópole campineira.

A ferrovia, em todos os casos citados, induziu o crescimento das respectivas áreas centrais até a estação central, mas também estabeleceu nela um forte limite do centro. Mais que isso, as áreas do mesmo lado do centro se valorizaram diferencialmente daquelas que ficaram para trás da linha do trem, constituindo-se em marco norteador de diferenças locacionais, dando início, ainda no século 19, a um claro processo de segregação socioespacial. Para cima da ferrovia - ou, em Campinas, para norte e nordeste da linha tronco da Cia. Paulista - era maior o interesse dos capitais imobiliários, das elites, do Estado com suas normas e sua aplicação, seus investimentos, conseqüentemente, maior interesse dos setores de comércio e serviços. Para baixo da linha do trem, nas áreas menos favorecidas, aqueles que não podem pagar o preço das áreas adequadamente urbanizadas, bem servidas, os pobres.

Evidentemente, com o passar de décadas, mesmo as áreas inicialmente mais pobres, diante da proximidade das áreas centrais, separadas "apenas" pela ferrovia, acabam recebendo infra-estruturas urbanas que as valorizam, fazendo com que os mais pobres sejam, muitas vezes, expulsos dali. De qualquer forma, a inércia espacial (SANTOS, 1996) trabalha consolidando práticas dos atores imobiliários que acabam, sobretudo nas maiores cidades metropolitanas, realizando lançamentos que reforçam os vetores territoriais da segregação urbana.

No meio intra-urbano da metrópole campineira, a ferrovia, mesmo reduzida a transporte de cargas, mesmo nos locais em que a ociosidade é elevada, ainda se coloca como elemento físico-estruturador do processo de segregação socioespacial. Tal situação é notável nas paisagens urbanas de Americana, Nova Odessa, Sumaré, Campinas (em relação à linha da Cia. Paulista), Valinhos e Vinhedo, ainda que, para esses três últimos municípios, a rodovia Anhangüera seja elemento muito mais forte para compreender os processos mais atuais de segregação socioespacial.

\section{DO VAZIO AO ESPAÇO PÚBLICO: \\ POTENCIALIDADES DE REESTRUTURAÇÃO DA PAISAGEM E DO TERRITÓRIO METROPOLITANOS}

Não se pretende definir o que deve ou não ser feito com os antigos leitos ferroviários da região metropolitana de Campinas. Mas a leitura desses espaços e de sua inserção no território metropolitano permite aventar potencialidades de renovação da 
Do Vazio ao Espaço Público: Requalificando Paisagens, Reestruturando Territórios
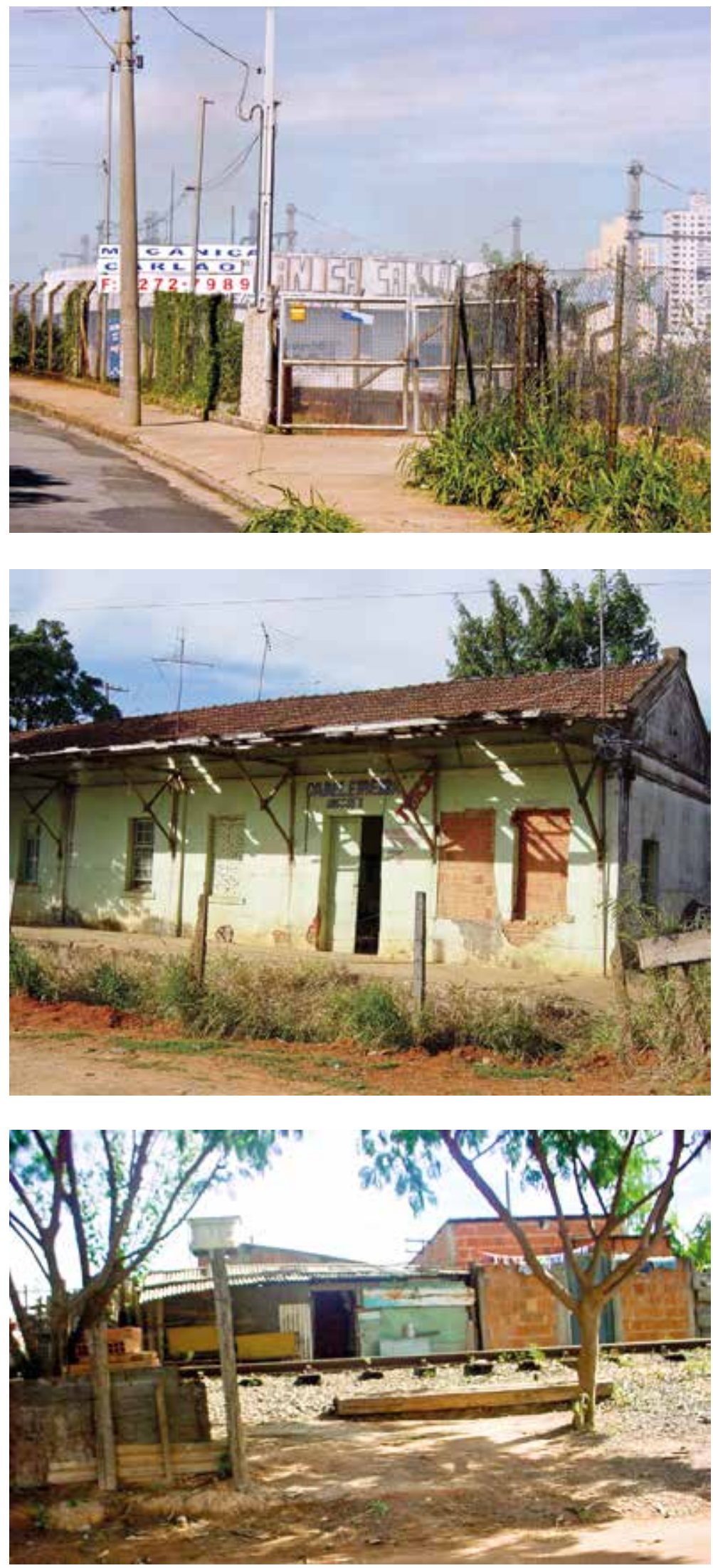

Figuras 12 e 13:

Estabelecimentos de serviço mais ou menos informais ocupando diferentes trechos desocupados da Sorocabana em Campinas Fotos: Queiroga, 2004

Figura 14: Uma situação de pracialidade bastante informal, criada junto do antigo leito da Cia. Paulista em Hortolândia. Entre o bar e o "banco da praça" passam, com freqüência, enormes composições de carga

Foto: Queiroga, 2004 
paisagem que podem ir muito além das áreas em si, eventualmente participando de uma reestruturação do território metropolitano. Apresentar essa possibilidade é contribuir para o debate, tanto acadêmico quanto no âmbito da gestão pública, sobre o futuro dessas áreas.

Tendo em vista que a desativação de vários dos antigos leitos ferroviários vem ocorrendo de maneira paulatina, corre-se o risco de propostas mais sistêmicas poderem ser inviabilizadas em poucos anos, se não forem tomadas algumas medidas de proteção no curto prazo. Alguns fragmentos dessas áreas já estão precariamente ocupados pelos mais diversos usos: de ferros-velhos a oficinas mecânicas, de habitações clandestinas a estacionamentos de shopping centers. Mas, ao menos por enquanto, nada que torne impeditivo recuperá-las para uso público.

Evidentemente, ações pontuais de preservação são louváveis. Vários municípios, pretendendo salvar as antigas estações centrais, transformam-nas em pequenos museus ou centros culturais. Quase sempre são parcos os recursos e grandes as dificuldades de programação de atividades, resultando em espaços pouco utilizados - Valinhos, Sumaré, Nova Odessa, Jaguariúna e Santa Bárbara. Diante da escala do patrimônio ferroviário, a Estação Cultura e o Ceprocamp (centro profissionalizante), implementados na Estação Campinas pela gestão Izalene Tiene (2001-2004) são iniciativas pouco relacionadas e que subutilizam o espaço de mais de $300 \mathrm{mil} \mathrm{m}^{2}$.

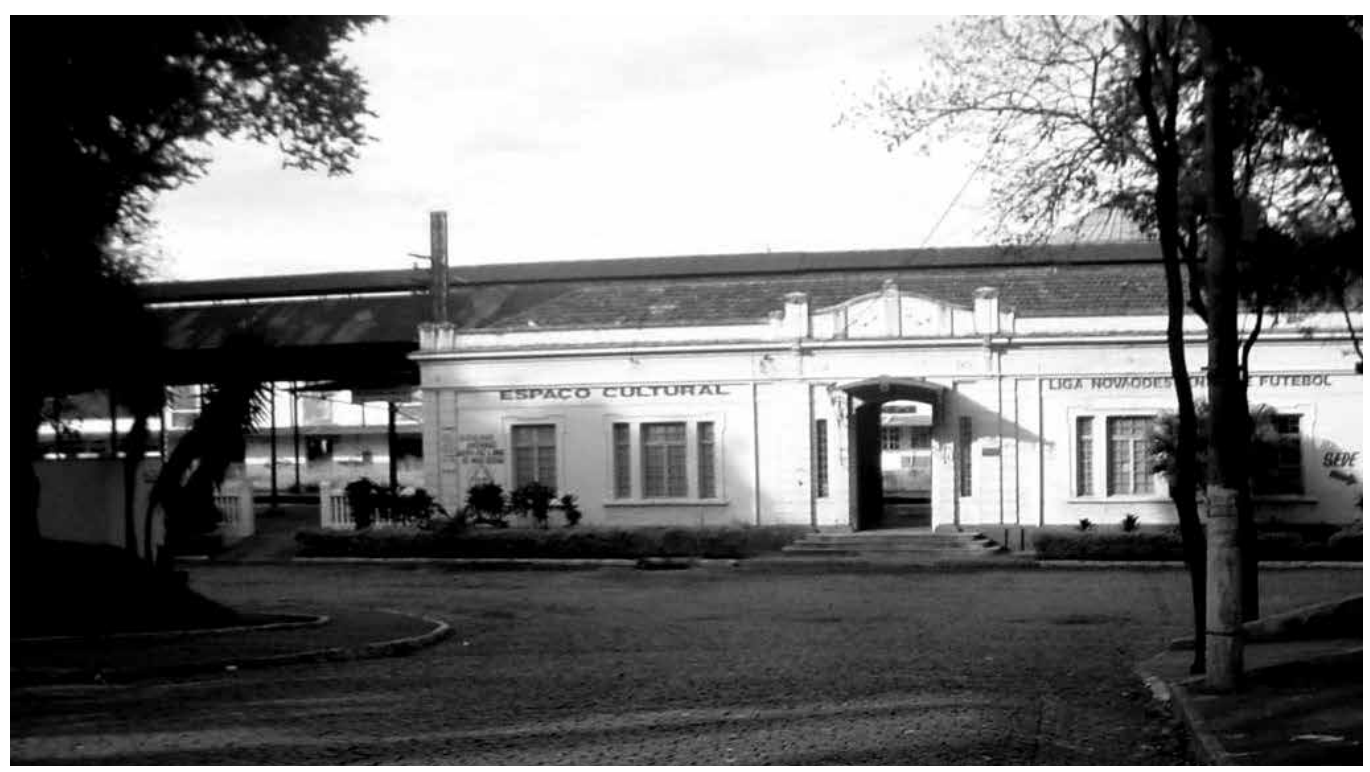

Figura 15: A antiga Estação Ferroviária de Nova Odessa abriga, agora, um pequeno "Espaço Cultural" e a Liga Novaodessense de Futebol

Foto: Queiroga, 2004

Alguns municípios, como Jaguariúna, Americana e Santa Bárbara d’Oeste chegam a transformar parte das áreas dos antigos leitos ferroviários, até as margens dos rios, em parques públicos. Aqui também se observa um baixo nível de investimento público, resultando, novamente, em pequena apropriação pela população. 
Via de regra observam-se medidas pontuais e tímidas de requalificação dos antigos leitos férreos, que pouco contribuem para a qualificação das áreas do entorno e pouco valorizam o patrimônio ferroviário. São melhores que nada.

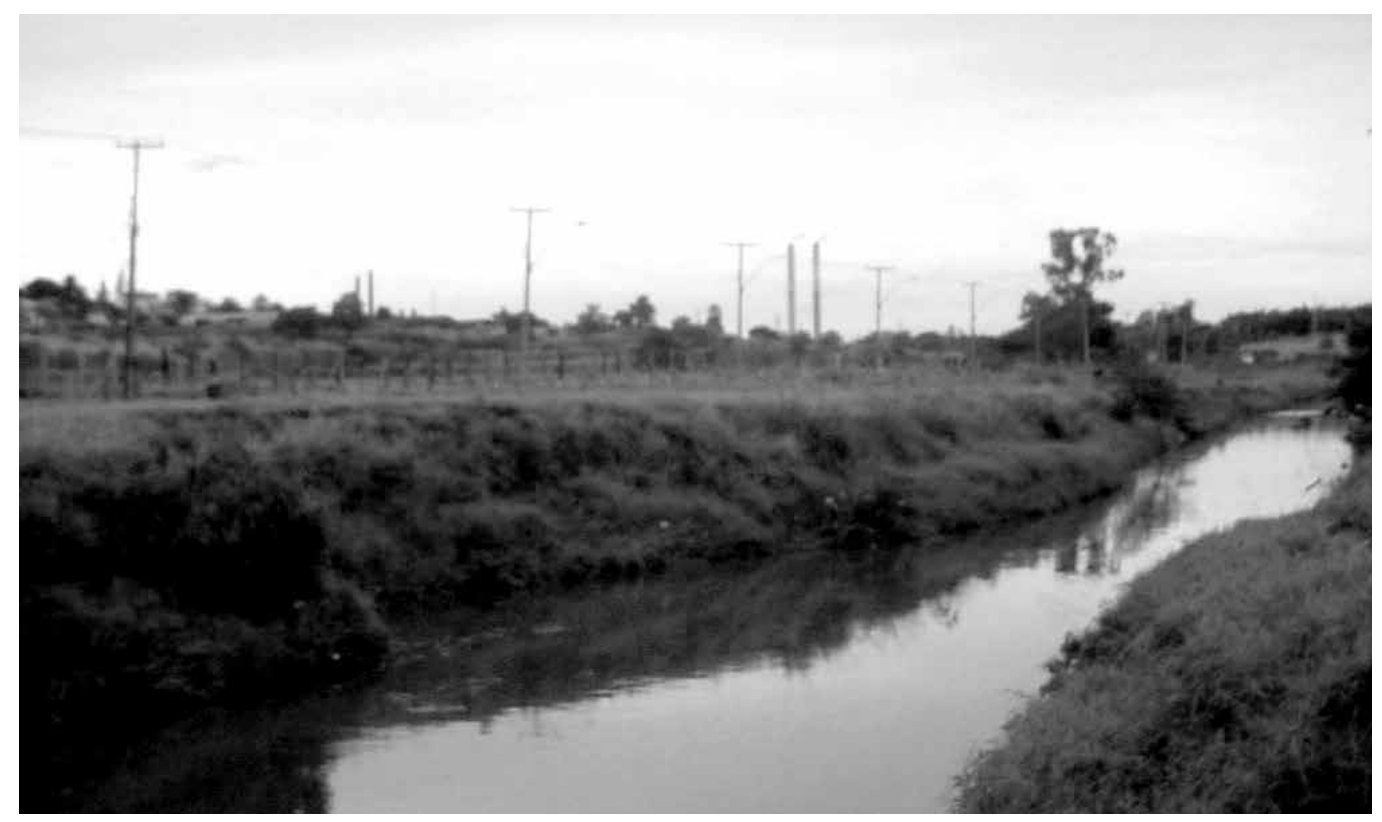

Figura 16: Parque linear entre o rio Quilombo e a ferrovia, em Americana, área praticamente abandonada Foto: Queiroga, 2004

O principal aspecto que se quer aqui salientar é a natureza potencialmente sistêmica do espaço dos antigos leitos ferroviários. Vale retomar o próprio entendimento santosiano do espaço, como conjunto indissociável entre sistema de objetos e ações (1989), o que nos auxilia não apenas a compreender o território, mas a refletir propositivamente sobre ele. De pouco adianta ao território metropolitano campineiro, em seus violentos processos de desenvolvimento desigual e combinado, ações isoladas e tópicas dessa ou daquela municipalidade.

Os antigos leitos ferroviários se constituem em áreas enormes, centenas de hectares, mas o melhor é que são áreas relativamente estreitas e de grande extensão, todas conectadas entre si, passando por áreas centrais da maioria das cidades de região metropolitana, cruzando bairros consolidados e periféricos, áreas industriais, próximas a universidades e aeroportos, entre outros.

Sem dúvida, é bastante óbvia, e não por isso menos pertinente, a alternativa de reaproveitamento dos antigos leitos ferroviários para transporte, agora não mais para longas distâncias, mas para as escalas metropolitana e urbana. A prefeitura de Campinas realizou, ainda nos anos 80 , estudos bastante preliminares para o aproveitamento da linha tronco da Cia. Paulista para um T.I.M. - trem intrametropolitano. No início dos anos 90, na gestão de Jacó Bittar, com o apoio do governo do estado (gestão Quércia), implantou-se, em Campinas, um VLT - veículo leve sobre trilhos - ocupando parte dos antigos leitos da E. F. Sorocabana, entre a avenida das Amoreiras e a Estação de 
Campinas. Tal iniciativa acabou fracassando por vários motivos; faltou, sem dúvida, uma visão sistêmica que pudesse otimizar o empreendimento, integrando-o a outros modos de transportes, notadamente coletivos. Seria lógico tratar o VLT como meio troncal a receber passageiros de linhas de ônibus alimentadoras do sistema, mas isso não foi feito e o VLT acabou competindo com o ônibus em trajeto mais sinuoso e lento. Como ação isolada e pontual, a experiência não avançou para a gestão seguinte.

Em 2003, a EMDEC, empresa responsável pelo transporte urbano em Campinas, apresentou seu plano preliminar de transportes para Campinas, onde, novamente, propõe-se $o$ aproveitamento dos antigos leitos ferroviários para transportes urbanos sobre trilho. Dessa vez, trata-se de uma proposta bastante abrangente, ainda que preliminar e merecedora de maiores estudos de detalhamento. A EMDEC propôs, para a linha tronco da antiga Paulista, a implantação de um trem de maior capacidade, de escala metropolitana. Os antigos leitos da Sorocabana e da Mogiana prestariam-se à implantação de um veículo leve sobre trilhos - VLT, passando, possivelmente, como subterrâneo na área central, complementariam esse sistema troncal alguns corredores exclusivos de ônibus, como o já existente na avenida das Amoreiras, que se instalariam em todas as avenidas com grande número de linhas de ônibus. Além disso, a EMDEC ainda apontou para a possibilidade de tratar esse sistema troncal como eixos preferenciais de adensamento urbano, sendo, em sua proximidade, desejável um maior aproveitamento do solo, de modo a otimizar o uso da rede de transportes proposta.

A proposta da EMDEC é bastante interessante, mas, como empresa municipal, seu alcance metropolitano é limitado, ainda que seu pequeno quadro de planejamento estivesse em contato com a Empresa Metropolitana de Transportes Urbanos - EMTU, atual responsável pelos transportes metropolitanos nas três metrópoles paulistas. Poder-se-ia

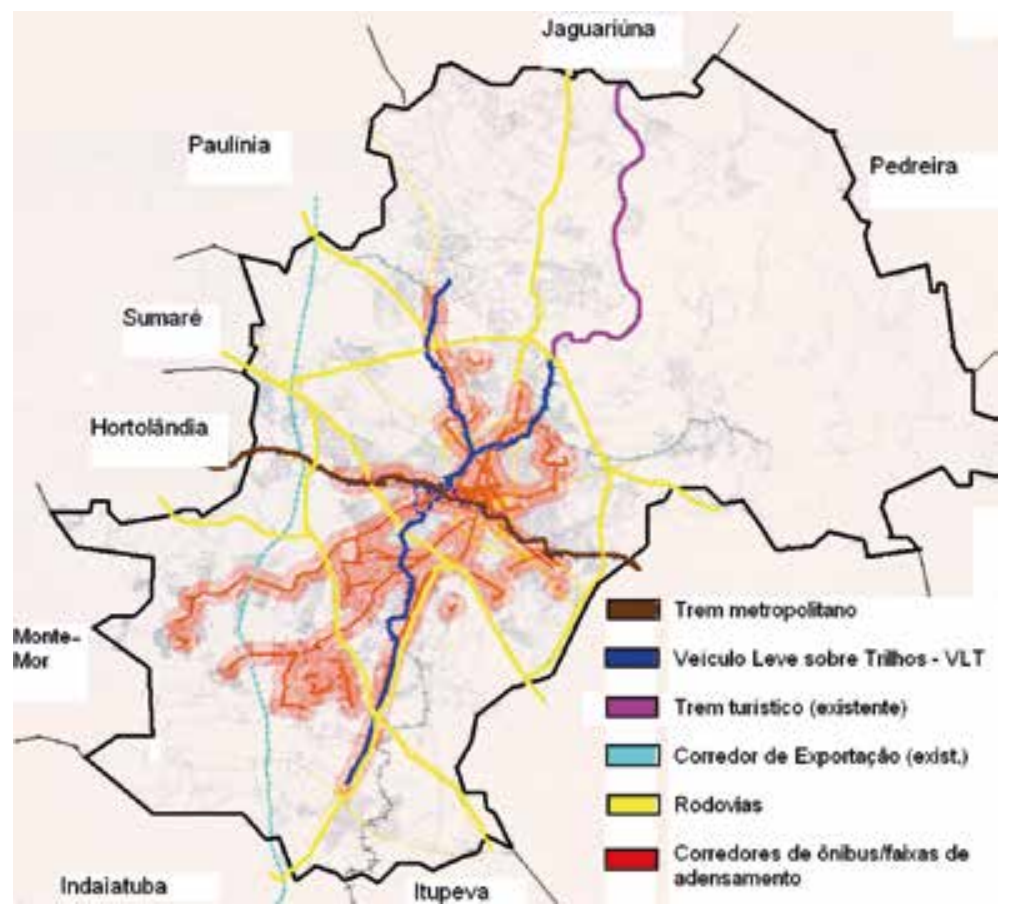

Figura 17: Proposta da EMDEC para um sistema estrutural de transportes para Campinas Desenho: Queiroga, 2005);

base: EMDEC, 2004 
sugerir que os princípios de aproveitamento propostos para os antigos leitos ferroviários do município de Campinas, fossem, via de regra, adotados para a região metropolitana de Campinas. Tal possibilidade seria implementada paulatinamente, na medida em que houvesse, em cada município, demanda para a instalação de transportes sobre trilhos.

Também seria de interesse metropolitano o adensamento urbano em faixas paralelas aos possíveis novos transportes sobre trilhos, VLT e pré-metrô de superfície, este último a ser instalado na linha tronco da Cia. Paulista, entre Vinhedo e Americana. Para o pré-metrô, visto sua maior capacidade de transportes e maior distância entre estações, seria recomendável um maior adensamento nas proximidades das estações, reforçando centralidades preexistentes e, por vezes, ainda pouco adequadas à escala urbana. Essa é, sem dúvida, a situação do acanhado centro de Hortolândia, em nada condizente com uma cidade de mais de 180 mil habitantes.

É provável que esse adensamento resultasse em um processo de verticalização cujas dimensões deveriam ser calculadas e debatidas pelas práticas de planejamento participativo. Assim, valeria contar, a metrópole, com uma estrutura adequada de transportes coletivos e uma paisagem estruturada de forma legível a seus usuários, organizando verdadeiros "corredores metropolitanos" (CAMPOS, 1972), cujos desenhos e usos não seriam impostos a priori, mas resultariam das especificidades dos lugares de cada cidade metropolitana e da interlocução entre o poder público, a população envolvida e os empreendedores. Nesse sentido esses corredores afirmariam identidades locais, unidades de paisagem próprias a cada contexto socioambiental, não se colocariam como um modelo único, como ocorre em Curitiba.

Compreendidos os antigos leitos ferroviários como elementos de escala metropolitana, é possível ir além da importante questão dos transportes e mesmo da relação entre infra-estrutura de transportes e adensamento urbano. É desejável uma leitura ainda mais ampla das potencialidades de inter-relação entre diferentes sistemas territoriais metropolitanos e o possível aproveitamento dos antigos leitos ferroviários. Sem pretender esgotar esse enfoque, apontamos abaixo para algumas outras possibilidades de papéis metropolitanos a que se poderiam prestar os antigos leitos férreos.

Do sistema ambiental, notadamente relacionado aos elementos do suporte biofísico, vale retomar a questão da proximidade da maior parte dos antigos leitos férreos a cursos d'água. Essa situação permite avaliar como positiva a destinação dessas áreas para a estruturação de um sistema metropolitano de parques lineares. Esse sistema, inexistente até o presente, propiciaria diferentes graus de apropriação humana e do restabelecimento e conservação dos ecossistemas preexistentes, hoje bastante degradados. As APPs (áreas de preservação permanente) junto desses cursos d'água teriam, assim, melhores condições de cumprirem seu papel ambiental, constituindo um sistema de corredores ecológicos capaz de interligar diversas matas residuais ainda existentes no território metropolitano. A experiência tem demonstrado que, para as áreas urbanas, melhor do que a simples exigência legal de proteção permanente das margens dos cursos d'água é permitir certo grau de apropriação e interação entre um sistema de proteção ambiental e um sistema de áreas livres de lazer. 


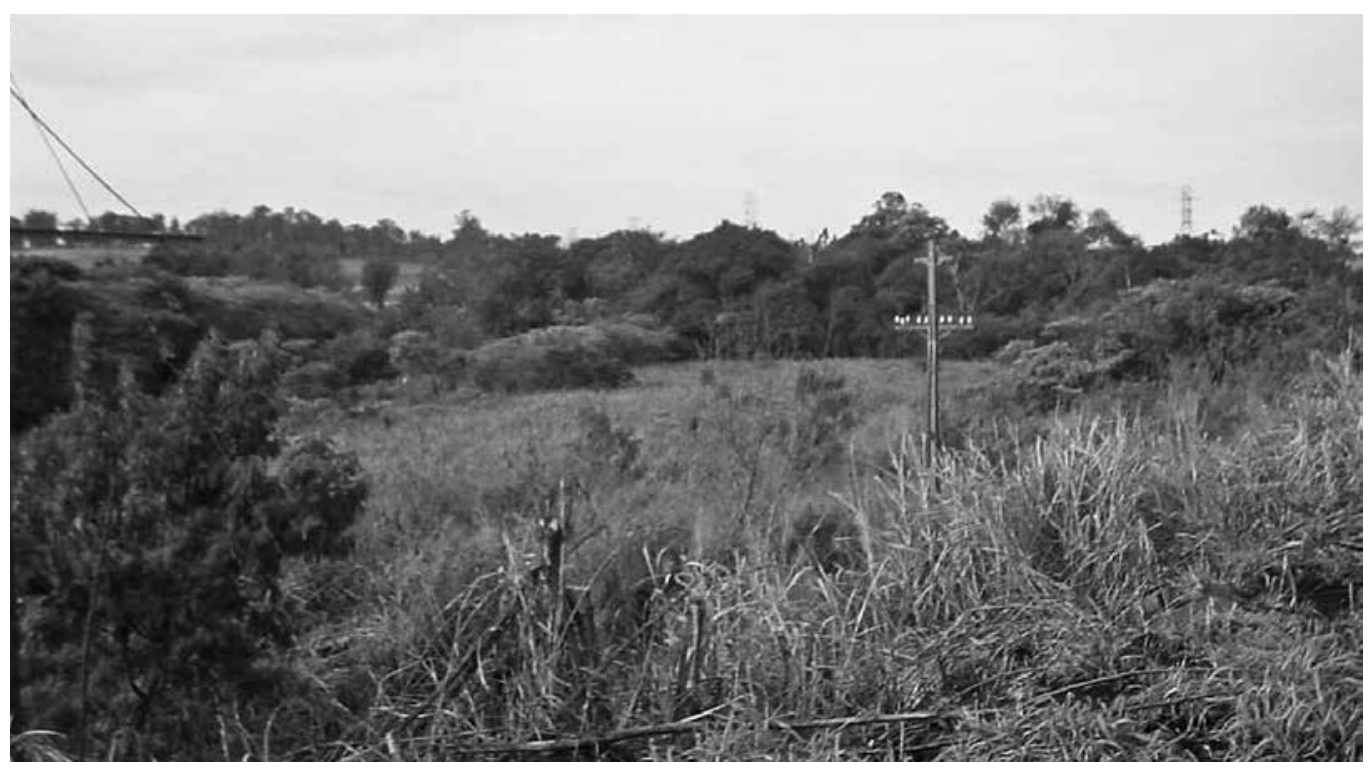

Figura 18: Uma situação típica dos vazios urbanos junto dos antigos leitos ferroviários da metrópole campineira: fragmentos de mata ciliar bastante alterados, vegetação de várzea, equipamento ferroviário abandonado. Trecho de vale do rio Quilombo em Nova Odessa

Foto: Queiroga, 2004

Evidentemente, é desejável que todo o sistema hidrográfico da região metropolitana viesse a constituir esse sistema de parques lineares e corredores ecológicos, mas os custos de implantação e manutenção impedem tal medida em curto e médio prazos. $\bigcirc$ aproveitamento dos antigos leitos ferroviários para a criação conjunta de parte relevante de um sistema metropolitano de transportes e de um sistema metropolitano de parques lineares poderia trazer benefícios mútuos. Os parques e o transporte ferroviário, valorizando as áreas, atrairiam os empreendedores para que se realizasse, em suas imediações, o conveniente adensamento - heterogêneo quanto a usos e tipologias; esse, por sua vez, reforçaria a utilização do transporte ferroviário e dos parques. Por outro lado, essa rede de transportes concederia ampla acessibilidade aos parques que poderiam, dessa forma, melhor cumprir seu papel socioambiental.

Os antigos leitos ferroviários também se prestariam à instalação de trens turísticos, articulando a metrópole campineira a outras localidades. Atualmente, na região, há apenas uma linha em operação, trata-se de trem a vapor partindo da Estação Anhumas, em Campinas, até Jaguariúna. Estudos recentes do BNDES indicam a viabilidade econômica para a instalação de trem turístico entre Campinas e Poços de Caldas - MG. Além disso, outras municipalidades, como Araraquara e Limeira, vêm levantando a hipótese de um projeto de trem turístico até Campinas, propondo, inclusive, a integração de programações de secretarias municipais de cultura, esporte e turismo a esse transporte. São estudos os quais requerem investimentos maiores do que podem arcar, no presente, os poderes públicos municipais envolvidos, mas que denotam a potencialidade de aproveitamento dos antigos leitos ferroviários também para esse fim, de forma alguma incompatíveis com as propostas acima sugeridas, pelo contrário, complementares. 


\section{PAISAGENS PARA O CIDADÃO DA METRÓPOLE CONTEMPORÂNEA}

O sistema de parques lineares, paralelo ao sistema de transportes sobre trilhos e envolvido por faixa preferencial de adensamento urbano de usos diversificados, em muito propiciaria a valorização da esfera de vida pública, ampliando as possibilidades de convivência em espaços públicos qualificados.

Essa renovação da paisagem certamente ampliaria a qualidade de vida metropolitana, constituindo-se em fator de atração de capitais para novos investimentos, tanto no setor secundário de alta tecnologia quanto no terciário. Promover-se-ia, então, não apenas uma renovação da paisagem, mas uma reestruturação no território metropolitano, hoje marcado por processos de segregação socioespacial, criação de enormes "enclaves fortificados" (CALDEIRA, 2000), fragmentação urbana ao sabor dos interesses imobiliários, valorização da esfera de vida privada e do espaço voltado ao grande capital corporativo.

É possível pensar em redes complementares, nas quais as eficientes auto-estradas da região não se constituiriam no único vetor estruturador de grandes investimentos - imobiliários, de lazer, consumo e produção - hoje altamente segregadores, mas onde se entrecruzassem os sistemas de transporte individual e coletivo, os sistemas de espaços públicos de caráter metropolitano e os equipamentos de lazer e consumo de abrangência ainda mais ampla, os interesses do grande capital e do grande público, da metrópole corporativa e da cidadania.

Evidentemente, essas possibilidades, tecnicamente viáveis no médio e longo prazos, demandariam prévio e amplo debate social e político. Nesse campo, o Estatuto da Cidade vem possibilitar, mas não garantir, a participação popular e a intervenção na propriedade privada urbana, a fim de garantir o cumprimento de sua função social. Enfim, a possibilidade de realizar-se a produção de paisagens metropolitanas, considerando não apenas o capital e os estratos de melhor renda, porém ampliando a cidadania aos pobres, o gozo público do território a todos os homens. Cabe despertar a questão e apontar potencialidades para que os vazios se transformem em espaços da esfera de vida pública, não isoladamente, mas sistemicamente.

Paisagens não são apenas resultados dos processos sociais, mas podem ser elementos fundamentais para a qualificação de espaços metropolitanos. Obviamente, não se trata de receita, mas princípio de método. Salientar a questão da paisagem como parâmetro a considerar em propostas de requalificação urbana e mesmo de reestruturação do território em escala regional, conforme exemplificamos para o caso dos antigos leitos ferroviários da região metropolitana de Campinas.

A leitura e a proposição da paisagem não se colocam dentro de um escopo empiricista, é necessário "desvelar a paisagem" (EMMANUEL DOS SANTOS, 2002), lê-la e não simplesmente vê-la, como diria Ferrara (2002), com uma abordagem ao mesmo tempo sistêmica e dialética, avançando nas trilhas fundamentais deixadas por Milton Santos (1978 e 1996, para citar apenas os trabalhos teóricos de maior fôlego 


\section{do grande geógrafo), nas pistas sempre instigantes apontadas pelos questionamentos de Miranda Magnoli (2004).}

\section{Bibliografia}

BITENCOURT, Ana Carolina. Um lugar de muitos lugares - espaços, valores e atividades: Uma leitura dos espaços livres públicos junto aos antigos leitos ferroviários de Campinas. 2004. 119 p. Relatório de Iniciação Científica - Faculdade de Arquitetura e Urbanismo do Centro de Ciências Exatas, Ambientais e Tecnologias, Pontifícia Universidade Católica de Campinas, Campinas, 2004.

CALDEIRA, Teresa. Cidade de muros: Crime, segregação e cidadania em São Paulo. Tradução de Frank de Oliveira e Henrique Monteiro. São Paulo: Ed. 34/Edusp, 2000.

CAMPOS FILHO, Cândido. Desenho para São Paulo: O corredor metropolitano como estrutura urbana aberta para a Grande São Paulo. 1972. 207 p. Tese (Doutorado) - Faculdade de Arquitetura e Urbanismo, Universidade de São Paulo, São Paulo, 1972.

EMDEC. Prefeitura Municipal de Campinas. Câmara temática de transporte e sistema viário. Campinas: EMDEC, 2004. CD-ROM.

EMPLASA. Metrópoles em dados. Disponível em: <http://www.emplasa.sp.gov.br/metrodados>. Acesso em: 28 jan. 2004.

FERRARA, Lucrécia. Design em espaços. São Paulo: Rosari, 2002.

IBGE. Cidades@. Disponível em: <http://www.ibge.gov.br/cidadesat>.Acesso em: 29 jan. 2005.

MAGNOLI, Miranda. Pesquisas em Paisagem e Ambiente. In: VII ENEPEA - Encontro Nacional de Ensino de Paisagismo em Escolas de Arquitetura, 2004, Belo Horizonte. Anais... Belo Horizonte: UFMG, 2004. CD-ROM.

PORTAS, Nuno. Tendências do Urbanismo na Europa. Óculum, Campinas, n. 3, p. 4-13, 1993.

QUEIROGA, Eugenio. A megalópole e a praça: O espaço entre a razão de dominação e a ação comunicativa. 2001. 351 p. Tese (Doutorado) - Faculdade de Arquitetura e Urbanismo, Universidade de São Paulo, São Paulo, 2002.

SANTOS, Emmanuel Antonio dos. As paisagens do plano e os planos da paisagem: Da paisagem no planejamento ao planejamento com a paisagem. 2002. 206 p. Tese (Doutorado) - Faculdade de Arquitetura e Urbanismo, Universidade de São Paulo, São Paulo, 2002.

SANTOS, Milton. Por uma geografia nova: Da crítica da geografia a uma geografia crítica. São Paulo: Hucitec, 1978. . (1988). Metamorfoses do espaço habitado. 4. ed. São Paulo: Hucitec, 1996.

Técnica, espaço, tempo: Globalização e meio técnico-científico-informacional. São Paulo: Hucitec, 1994. . A natureza do espaço: Técnica e tempo, razão e emoção. São Paulo: Hucitec, 1996.

2000. Por uma outra globalização: Do pensamento único à consciência universal. Rio de Janeiro: Record,

SOUZA, Maria Adélia. Cidades médias e desenvolvimento industrial - Uma proposta de descentralização metropolitana. São Paulo: Secretaria de Economia e Planejamento do Estado de São Paulo, 1978. 